\title{
CHILDREN IN WAR SITUATIONS:
}

\section{THE CASE OF AFGHANISTAN}

\section{By}

\section{Carl Schönmeyr}

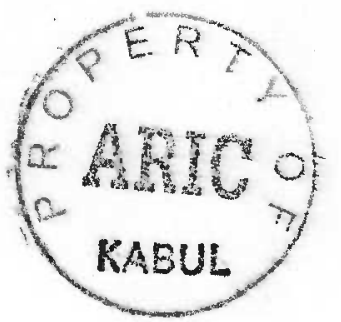

Islamabad, 1 February 1985 
On Christmas Eve 1979, Soviet troops invaded Afghanistan.

Units of the 105th Airbone Division captured Kabul Airport in a surprise attack which paved the way for a subsequent airlift of supporting units from the 103rd and 104 th Divisions, all elite paratroopers whose assignument was to take control of the capital. The objective was achieved within days. In the process, a K.G.B. hit souad killed Afghanistan's Prime Minister, llafizullal, $\mathrm{Amin}$, together with menbers of his family, in an assault attack against the Darulaman Palace.

Simultaneously, motorized divisions entered Afghanistan from the Soviet border, covered by aircraft, to link up with the airborne troops in . Kabul.

On 28 Decernber 1979, Kabul Radio announced the death of llafizullah Nnin and his replacenent by Babrak Karmal, a pro-Soviet Afghan conmunist living in political exile in the Soviet Union. Babrak Karmal was brought to Kabul with the first wave of invading soviet troops. His first speech to the Afghan nation, on 27 Decenber, was broadcasted, on pre-recorded tapes, from the Soviet Union.

The official soviet explanation of its military action was that it was carried out in response to a "request" from the Afghan Government made on 26 Dccenier. llowever, at that time, Babrak Karmal had not yet arrived in Afghanistan. Accordingly, the official Soviet explanation was met with undorstandable scenticism in the international community. Many countries in particular Islamic countries - refused to recognize the Babrak Karmal governmont. Others - including a number of Western countries - maintained their colvassies in Kabul and their diplomatic ties with the Babrak Kamal governnent, presumably in an effort to monitor the situation and keep the docrs cpen to a possible political settlement of the crisis at a later stage. The latter policy resulted in the anomaly of Babrak Karmal's government, as far as the United Nations is concerned, still being allowed to speak for Afghanistan in the General Assembly and in other U.N. bodies.

\section{The Legal Fiction}

The legal fiction of sovereignity and of the legitimacy of the Kabul govenment, has constituted a main obstacle to U.N. humanitarian action in Afghanistan. Whereas Afghanistan in reality lost its sovereign status as a result of the Soviet invasion in December 1979, and although its present governnent enjoys no more credibility in the country than Vidkun ouisling's government in Norway during World War II, the voice of Afghanistan in the United Nations remains that of Babrak Karmal.

The legal fiction has also confronted the United Nations with other problems with regard to the Afghan situation:

a) The Secretary-General's negotiations regarding a political settlement is being carried out between the Babrak Karmal govcrnment and the governmont of Pakistan - excluding representatives of the Afghan people; 
b) UN agencies represented in nfghanistan - including UNICEF maintain their presence in Kabul and continue their collaboration with the Babrak Kannal Government. Their activities are, however, for all practical purposes, limited to the capital itsclf. Nothing can be done, through Kabul, to reach the majority of the Afghan civilian population living in rural areas not controlled by the Babrak Karmal government;

c) as a result, a huge part of the country (approximately 808) has developed into a "social catastrophe zone", deprived of the most basic necessities of life and, so far, totally ignored by the United rations agencies concerned with social and humanitarian assistance.

In UNICFF tenns, the consequences of the "legal fiction approach" can be illustratad as follows: an Afghan child who is sick, wounded, malnourislicd, or starving can get help either if it lives in Kabul or in the main citics under Government control, or if it has crossed the border and become a refugce. If it lives inside Afghanistan, in any of the thousand of villages where the majority of the people still hold out against the invaders and their $\Lambda$ fghan allies, this child will get no help whatsoever. It will be left to survive as best as it can - against the effects of high altitude bonbings, strafing and shelling, starvation tactics, disease, disnuption of family life, and collapse of its traditional environment. These clibldron constitute the majority of the Afghan children remaining inside the country to-day.

Against this bacground - who can blame the Afghans for being very bitter against the Unitcd Nations? The contrast between the "business as ustal" approach of the UN agencies in Kabul and the complete lack of concern by the same agencies for the suffering civilian population living outside the min citics in apalling conditions, is seen as cynical opportunism and a negation of the very principles which the United Nations stand for.

\section{The Demography of a Social Catastrophe}

To try to estimate the disruptive effects of five years of foreign coupation and warfare in a country which never had a reliable census is, naturally, a very difficult task. The true picture is not known and will never be known. Nevertheless, some estimates - basically to get an idea of the magnitude of the problem - can be made, however uncertain:

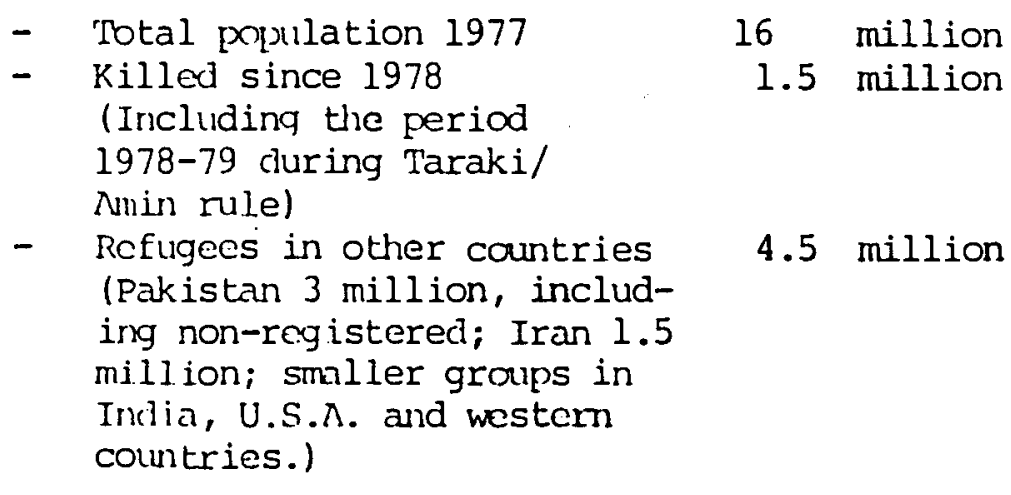




\section{- Remaining inside Afghanistan}

- Feople living in Governmentcontrolled areas, mainly urban

- Pcople living in areas not controlled by Govermment, "Free Afghanistan", mainly rural.
10 million

3.5 million

6.5 million

The $\lambda$ fghan refugee population in Pakistan comes mainly from the eastern (pushtu-speakim) provinces. Recently, increasing numbers of refugees from the north (turkmen, uzbeks, tajiks) have been registered, probably reflecting the worscning situation in the north. This population contains a high proportion of women and children.

'Ihe Afghan refugee population in Iran, coming from the western, southwostern and the central (llazaru) provinces, contain a relatively less proportion of women and children. Most $A$ fghan refugees in Iran do not live in canps; the Afghan hazaras in particular tend to leave their families bohind and go to Iran to take jobs.

Within the country, there has also been important movements of the population, mainly from country to city, and as an example can be shown the growth of the pxpulation of Kabul, which in 1972 was about 600,000; in 1978 about 800.000-1.000.000; and in 1984 about 2.000.000. Among approximately 3.5 million, living in Government-controlled areas, most are rcsidents of the min citjes, the only territory apart from airfields and garrisons, which is actually under Government control.

The internal refugecs, or displaced persons, who have left their homes, but have neither gone to the cities, nor left Afghanistan, presently number about 0.5 million, and reside, sametimes even without any tents or houses, scattered over mountainous areas, where caves in the mountains give protection from air-raicls. These people, who have the same age and sex distribution as the other parts of the population, probably live under the worst conditions prevailing in Afghanistan at present.

The nonadic population, the "Kuchis", also experience frustrations on their regular routes, in the forms of air raids, mines, road blocks, and have dianged their pattern of movements, which has meant considerable changes in their lifestyle, and many have lost a considerable part of their animals and belongings.

In the central, mountainous region of nfghanistan, Hezarayat, the population has suffered less from regular anmy attacks. The region is so mountainous, that it is alnost impregnable. Instead, this region is kept under pressure by infiltration of the regime's intelligence agents, instigating the anncd population to fight each other. Traditionally one of the most impoverished areas of Afghanistan, llezarayat, now lacks all kinds of facilities, and its population is richly represented among the refugees around Quetta in Pakistan, and in Iran.

$$
\text { /... }
$$




\section{The Military Situation}

The war in Afghanistan has entered its sixth year; the Soviet armed intervention in the country has thus lasted longer than the soviet involvement in World war II.

A military stalemate has emerged: the Soviet anned forces and their Afghian governnent allies control the major cities - Kabul, Herat, Kandahar, Mzar-i-Sharif, Jalalabad - and provincial towns, air bases and military garrisons. They enjoy complete control over the airspace. The Afghan resistance movement and its various groups control the rural areas: mountains, valleys, sterpes and deserts. Main roads are disputed territory; all soviet and government road movements have to be done in convoys, under military escort, for protection against ambushes. Large areas have become depopulated "no nan's land", where all means of livelihood has been destroyed. The situation may cliange, pending the military operations: major soviet attacks, by air and by ground forces, lands to temporary withdrawal of the resistance forces to their mountain hide-outs. Wilen the bulk of Soviet forces pull back, the guerilla forces retum. In urban areas, the situation may change from day to night. In many cities (llerat, Kandahar) the resistance is strong and vell organized, carrying out underground operations in night time. Even the capital, Kabul, is frequently subject to bomb and mortar attacks organized by the underground resistance forces.

The $\Lambda$ fghan any - made up of conscripts - has proved to be a most unreliable ally to the Red Mrmy. Flagued by dissent, low morale and mass defections, it has molted down from 80,000 to 30,000 men. $\Lambda$ large part of the supply of arms, ammitions and equipment to the resistance comes from defecting units of the nfghan army. This situation has forced the soviet Union to engage its armed forces in battle on an increasing scale. The Afghan any can no longer be trusted.

The Soviet military forces in Afghanistan has, accordingly, gradually increased from 105,000 to an estimated present strength of 150,000 men. In addition, Soviet air and ground forces based on the Soviet side of the border is regularly used for operations in Afghanistan's northern provinces.

Western sources estimate that it would require at least 500,000 men Soviet troops to achieve an actual occupation of Afghanistan and the sealing off of its borders. This would probably not be a politically feasible solution. World opinion is becoming increasingly aware of what is going on inside Afghanistan. The sight of a superpower unleashing its modern technology of destruction on a poor, underdeveloped Asian country has already caused incalculable damage to the prestige and credibility of the soviet Union internationally. A further escalation of the Soviet military role in Afghanistan might therefore be a too high price to pay for military victory. Other mans are therefore being resorted to.

The strategy evolved over the last three years seems to imply that the cjvilian population, in particular the villagets living in areas of high military activity, is becoming the target of military as well as economic warfare. The logic of this strategy is clear: the fighters of the resistance movement are theniselves villagers who have taken up arms against the invaders. They depend on the village people for food and protection. If

$$
\text { /.. }
$$


their supply buse is destroyed and village support withdrawn or rendered impossible - then the resistance fighters will be forced to give up or go in exile.

The inplications of this strategy can be felt in Afghanistan in all areas of UIJICFF concern: shelter and clothing, health, food and nutrition, as well as human rights and Geneva conventions on war. This will be illustrated in the following.

\section{The Political Situation}

Internationally, the Soviet military intervention in nfghanistan was met with overwhelming indignation. Wile the United Nations Security Council was paralyzed by the Soviet veto, the General Assembly, in a resolution of 14 January 1980, called for the "imnediate, unconditional and total withdratal of foreign troops from Afghanistan" (No other foreign troops than Soviet ones are in Afghanistan.) The resolution was adopted by 104 votes acjainst 18, with 18 abstentions. The General $\lambda$ ssembly has since passed five similar resolutions, with even greater najority. Similar condenmations have bcon mule by the Islaunic Conference, the ASENN countries and the Duropean Commanity.

Ihe Ihuman Rights situation in Nighanistan during Soviet occupation has been highlighted in two Feople's Tribunals on Afghanistan (Stockholm 1981 and Faris 1982) and in one International llearing on Afghanistan (Oslo 1983). The proceedings of the latter are deposited with the Norwegian Ministry of nffairs. Nrmesty Intemational has drawn attention to the Iluman Rights situation in $\lambda$ fghanistan in several reports and the UN Commission on lluman Rights decided in 1984 to investigate conditions in Afghanistan.

Other UN agencies - including UNICEF - have remained silent.

Internally, the political scene has been characterized by continuous conflict betwcen the two factions - Khalq and Parcham - of the tiny, ruling comanist party, the People's Democratic Party of Afghanistan (P.D.P.A.). Since the party lacks a popular base in the country, it is entirely dependent on Soviet military, political and economic support. Its most effective instrument of control is the local K.G.B.-trained security police, K.H.A.D.

The resistance movement is split between one, "Fundamentalist" group of purties, the Islamic Alliance and one, "Liberal" group, the Islamic Unity. ilie parties belonging to these two alliances enjoy a semi-official status in Pakistan and have their offices in Peshawar.

A third, emerging force is the resistance based in the interior of the country, particularly in areas which have seen a new, charismatic and effective leaclership emerge (Massoud in Panjshir, Zabiullah in Mazar-eSharif and Ismail Khan in llerat). Many voluntary organizations concerned with humanitarian aid to the Afghans inside Afghanistan (the Swedish committee, the French doctors organizations) prefer to establish their own, direct links with the resistance leaders inside Aghanistan, bypassing the Peshawar-based, "political" parties. 


\section{The Social Situation}

Five years of war, declining agriculture, disruption of intemal commnications and the breakdown of social services and institutions has led to a social citastrophy involving millions of people. It is a "loud" emergency in the sense that it has been caused by war and the effects of war, but "silent" in the sense that it has been treated with silence and indifference by those UN arjencics whose mundate compels them to assist poor people in poor countries (FAO, WIIO, UIESCO, UNICET). This silence is not due to lack of information. On the contrary, information is available in abundance; there have been surveys carried out on the food and nutrition situation, investigations of the nature of Soviet methods of war and its consequences in Afghan villages, served in first-hand experience of more than 200 medical doctors who have served in various parts of $\lambda$ fghanistan. The continious influx of refugees mation alrady available. In view to monitor the situation and update inforbut not utilized, only one explanation these sources of information, available, offered: lack of "politicalanation of the silence of UN agencies can be tive to an influential menuer state touch a subject which is highly sensiAfghan pcople continues and the war against civilian, the sufferings of the without any cnikrassing debates in international fora or dissemination of
facts through international organizations.

It would he impossible to review, within the format of this brief paper, all the infomation available on the social situation inside Afghanistan. I will limit myself, therefore, to mention some of the main areas of needs, referring to sources of more detailed information.

llousing. Climate in Afghanistan is harsh, with great variations betwoen day and night, summer and winter. . Mountainous areas have snow temperaturcs below frcezing point in winter tine. Lack of housing can therefore result in cxtroine hardships and, sometimes, to mass exodus of populations, eithcr to ncarby side valleys or to more remote places inside Afghanistan or disraad. The effects of massive shelling, borbardments and high altitude bombing of villages can therefore be catastrophic. A case in point is Panjshir valley, nonmally the home of a population of $80,000-100,000$ people. It is estimated that, after seven major Soviet offensives in Panjshir, almost 808 porcent of housing is totally destroyed. The entire population has been rendered homeless.

Clothing. Lack of clothing - in particular woolen clothes and shoes is acute in areas of high altitude and high war activity. A sizeable proportion of the Panjshir population is now surviving in caves, in the Upper parts of the valley. These provide shelter against air attacks, but morbidity and mortality incrcase significantly, particularly in winter, when snow blocks the mountain passes tirough which relief supplies can be transported.

licalth Care. For the majority of the Afghan civilian population in rural areas of $\lambda$ fghanistan no health care is available whatsoever. Consegucntly, all previously existing programmes have broken down: there is no longer any malaria control and Turberculosis Control programmes and no Imminization projianme. A new generation of children is growing up without any protection against communicable diseases and children's diseases. In conbination with mlnutrition, lack of proper housing and clothing and direct whr casualties, the result on children's well-being has been devastating. Estimtes of current IMP vary between 300 to 400 per thousand. $A$ Swedish doctor, Jolian Iagerfelt, who served in llazarajat with one of the French voluntary organizalions in 1984, estimbtes IMR in that area to be around 400 . It should he pointed out, in this connection, that llazarajat is an area of 
of low war activity. In areas of high war activity, direct casualties constitute a major part of the morbidity pattern among children. A particularly abhorrent type of such casualties affecting children are those resulting from mines and booby-trapped toys. Dr. Claude Malhurst of Medecins Sans Frontieres (M.S.F.) has pointed out, in an article published in "Foreign Affairs" (attached) that these devices are not designed to kill, but to injure. M.S.F. field staff serving in $\lambda$ fghanistan has reported on the effects of booby-trapped toys (mostly in the shape of plastic pens or small red trucks). "The main targets are children whose hands and arms are blown off. It is impossible to imagine any objective that is more removed from conventional military strategy, which foreswears civilian targets". The aim of dropping anti-personnel mines is both to demobilize maximum number of resistance fighters (who need to carry the injured over long distances, whereas a dead person just has to be buried) and also to cause economic damage on the villagers. llumans can be taught to be careful, whereas animals keep being injured by the mines.

Sumnarizing his findings in a doctor's thesis submitted to the medical faculty of the Rene Descarter University in Paris, Dr. Gerard Kohont of MSF gives the following main causes of illness among the clvilian population inside Afghanistan:

- War injuries

- Tuberculosis

- Eye diseases (particularly Trachoma)

- Cironic upper respiratory infections

- Gastro-Enteritis

- Salinonella

- Worms and other intestinal parasites

- Malnutrition

- Rheumatical conditions

- "Le syndrome Afghan" (war neurosis), the consequences of physical and mental traumas.

Dr. K.A.M. Grant of Health Unlimited, in a report published in Julynugust 1984 (attached) recommends the establislument of a Pilot Primary Health Care Project inside Afghanistan, focussing on the following preventable diseases which he believes now play a major role in the mortality and morbidity patterns of the interior:

- Measles

- Pertussis

- Diarrhoea

- Dysentery

- Rcspiratory tract infections

- Ear infections

- Tuberculosis

- Seabies

- Malaria

- Worms

In the present situation, hardly any medical services are avallable to the civilian population in areas not controlled by the Kabul Government other than those provided by the three French voluntary organizations (keeping around 20 expatriate doctors in various locations in Afghanistan as an average at any point of tine) and those provided by Afghan doctors (partly based in Peshawar

$$
\text { l... }
$$


and travelling insidel supported by the Swedish Comittee for Afghanistan through its Peshawar office.

$\Lambda$ standard list of medical suppies provided by the Swedish committee is attached.

Paramedical personnel are trained in Peshawar by various groups (see attachment) and travel inside with the local commanders. Traditional practitioners are still active in the interior and pharmacies can be found in smaller towns and market places. However, in view of the total population served, 6 - 7 millions (and possibly more), the health situation in the interior is very serious and should become a matter of greatest concern to UN agencies such as WIIO and UNICTFF.

Food and Nutrition. The most recent study of this subject is "The Threat of Famine in Afghanistan" by Frances D'Souza and published in May 1984 (a copy of this document is available with Mr. Jacques Beaumont, Emergency Unit, UNICEF New York).

Availability of food differs considerably between urban and rural areas, between different regions of Afghanistan and, sometimes, even within a province. Because of the problems of transportation of food supplies from the Pakistan border into the interior, the Swedish conmittee has found it more convenient to provide cash assistance rather than supplies in $k$ ind, particularly to severely affected areas where the resistance movement is well organized and has a system of logistics and distribution of food which can be bought and transported from nearby, surplus areas (e.g. Panjshir).

A U.S. assessment tean (1984) took a less serious view of the acute food and nutrition problems in Afghanistan as a whole, but remained very concerned about the long term perspective. The team concluded:

" $\lambda$ ssessment team expressed deep concern regarding long term food availability within Afghanistan. A number of the critical factors necessary for continued food production and internal transport from surplus to deficit areas are deteriorating. Key factors would appear to be weather and soviet strategy toward civilian targets".

Education. In the field of Education, the consequences of war and occupation have been equally devastating.

In occupied areas - Kabul and major cities and towns - the traditional Afghan educational system has been deliberately dismemberd and replaced by a system adopted from the Soviet Union, with its heavy emphasis on Ideological indoctrination, compulsory studies of the Russian language, etc. A "russification" of the Afghan education is in progress. Part of this long-term effort to win the hearts and minds of the new generation is the rewards given to students who join the communist party. Another is the dispatch of large number - thousands, the exact figure is not known - of children, even young children, for studies in the Soviet Union.

In the rural areas, the education system has just broken down, without being replaced. The new generation of children in rural Afghanistan grew up illiterate, involved in the freedom struggle in one way or another, deprived of the security offered by the traditional, functioning system of normal, peaceful family and conmunity life. In some areas, however, where the resistance movement has introduced a system of local self administration and social services (Panjshir, Logar) schools are again operating, although under extreme hardship.and without access to teaching facilities, books, etc. 
$\Lambda$ comprehensive overview of the Afghan education situation is given in (attached).

Culture. The Afghan people is ethnically mixed, but culturally homogeneous because of Islam. To many resistance fighters, the ongoing war is as much a "holy war" against local and soviet communist "unvelievers", as a war of national liberation. Islam is a powerful element in the high morale of the resistance. The tactic of destroying mosques, use them as latrines for the invading troops, etc., which has been reported by foreign journalists and photographers, serves the purpose of demonstrating the futility of Muslim faith when confronted with the material superiority of modern "civilization" and to humiliate the defeated and their beliefs.

So far, this tactic seems to have been counterproductive and streng thened rather than weakened, the will to resist.

\section{The lluman Rights Situation}

\section{Urban areas}

Rural areas

The most camprehensive study of the Iluman Rights situation in $\mathrm{N}$ ghanistan is the sturly "Tears, Blood and Cries" recently (December 1984) published by IIELSIITIY MNTCI. A COpy is available with Dr. B. Namazi. The study covers crines against the rural population (Indiscriminate bombing, reprisal killings and massacres, anti-personnel mines, arrest, forced conscription and torture, destruction of the rural economy) and against the urban population. (suppression of Freedom of expression, association, assembly and movement and human rights).

The report deals wi.th the methods of torture in Government interrogation centres in Kabul and with the conditions in Afghan jails.

It also deals with the Kabul Government's efforts to prevent medical and humanitarian assistance to the population living outside government control, its treatment of journalists, and French doctors and its Fefusal to allow international control and inspection.

The study quotes, in the introduction, the words of an Afghan resistance leaders "A whole nation is dying. People should know".

To my knowledge, the study - unfortunately - does not exaggerate. It presents, as far as I know, the truth - in all its horrifying dimensions. It is an invaluable source of infonation on today's Afghanistan.

\section{What Can be Done?}

The possible options for an organization like UNICFF, in the face of the social catastrophe inside Afghanistan, would have to be thoroughly discussed and cannot by dealt with satisfactorily in a paper of this nature. The following are just some indications of possible action.

\section{Direct Assistance}

Direct assistance to the Afghan civilian population living in nonGovernment controlled areas would have to be negotiated with 3 parties: 
(1) The Govermment of Pakistan (or, in the future, the Government of Iran, when political conditions permit); (2) the Kabul Government and (3) Representatives of those resistance groups which control the area through which
relief personnel or relief supplies would have to move.

Such negotiations would, in UNICEF's case, probably have to be carried out by the Executive Director according to a broad madate given to him by the
Executive Board.

\section{Indirect Assistance}

Indirect assistance can be given through any humanitarian organization, Afghan or expatriate, which is based in Pakistan and have access to the civilian population inside Afghanistan. An overview of existing humanitarian organizations involved in assistance to the Afghan people is attached.

\section{Monitoring}

An irmortant task of UNICEF (as well as WIO, FAO, UNESCO) would be to continously monitor the situation inside Afghanistan, in order to give appropriate "warning sigmals" to the international community and to be able to be adequately informed, at any given point of time, about the situation. Such monitoring can be done in Peshawar (and in Paris, in collaboration with the French voluntary organizations.)

\section{Advocacy and Information}

The five-year long silence about the fate of Afghan children and mothers inside $\Lambda$ fghanistan has acted as major incentive for trapping up military and economic warfare directed against the civilian population. If even organizations like UNICEF prefer to keep silent and abstain from the dissemination of any information regarding the conditions of Afghan children - what better evidence could there be that continued terror tactics will pay off, with no or minimal embarrassment to the agressor? The Afghan situation is one where UNICEF's role as "Advocate and spokesman for children in need, whereever they are" can, if exercised, lead to an immediate effect. There is a long period of silence to make up for - five years ...

\section{International Conventions}

The value of international conventions - if not monitored - can be questioned. The present Soviet warfare in Afghanistan is a case in point; it involves the violation of a number of international conventions on a large
scale and in a systematic manner.

Nevertheless, the Swedish initiative regarding "Children as a neutral Zone" could be worthwille to pursue.

\section{Implications to UNICEF}

Failure of UNICEF to act - directly, indirectly or in terms of advocacy and dissemination of information - could greatly compromise the organization as an international, humanitarian organization concerned with the 
$-11-$

survival of children. The situation of the Afghan child today is one of sheer survival. UNICEF must not and cannot be indifferent. 


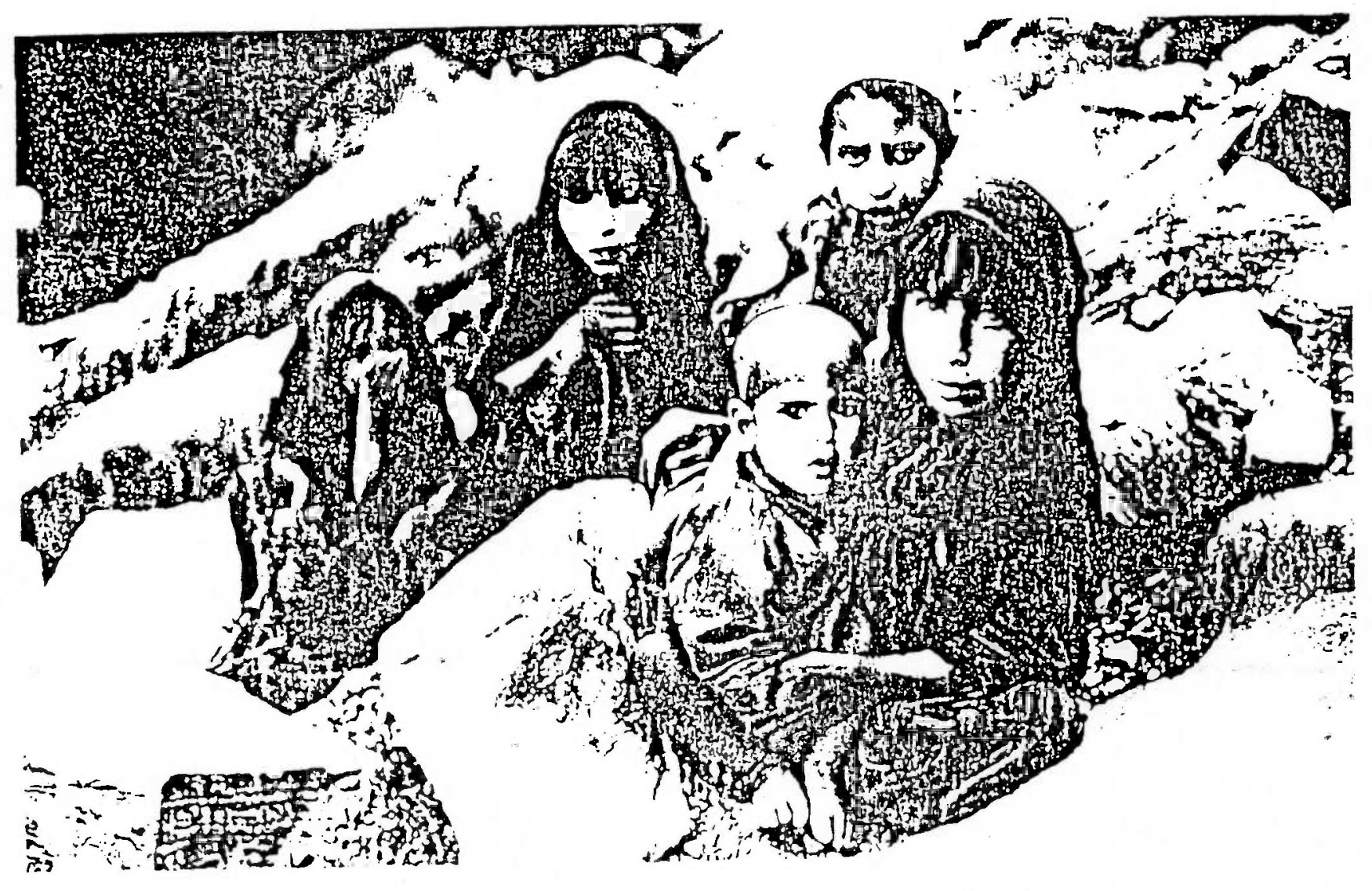




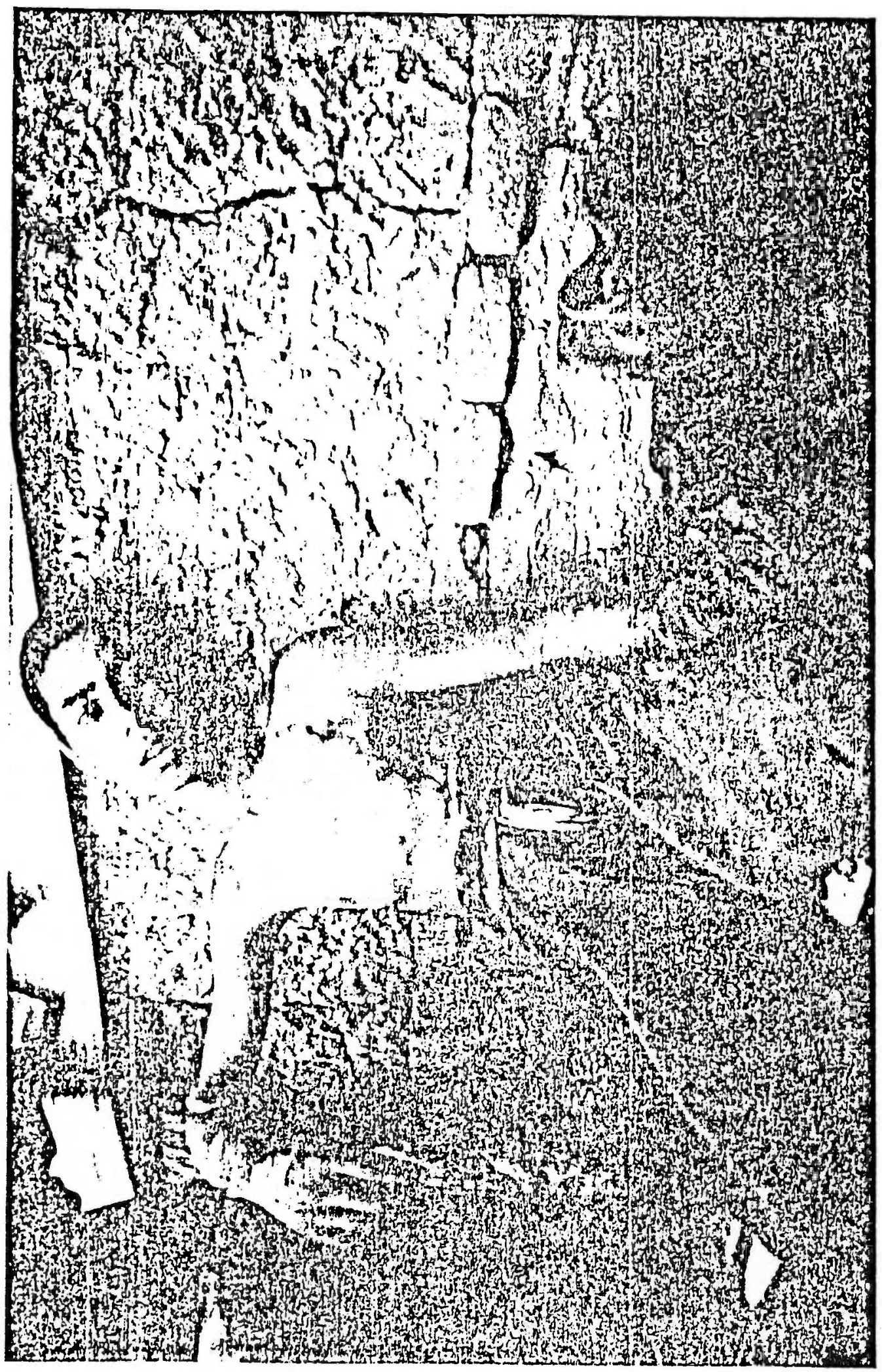

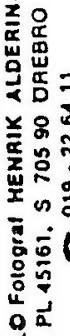




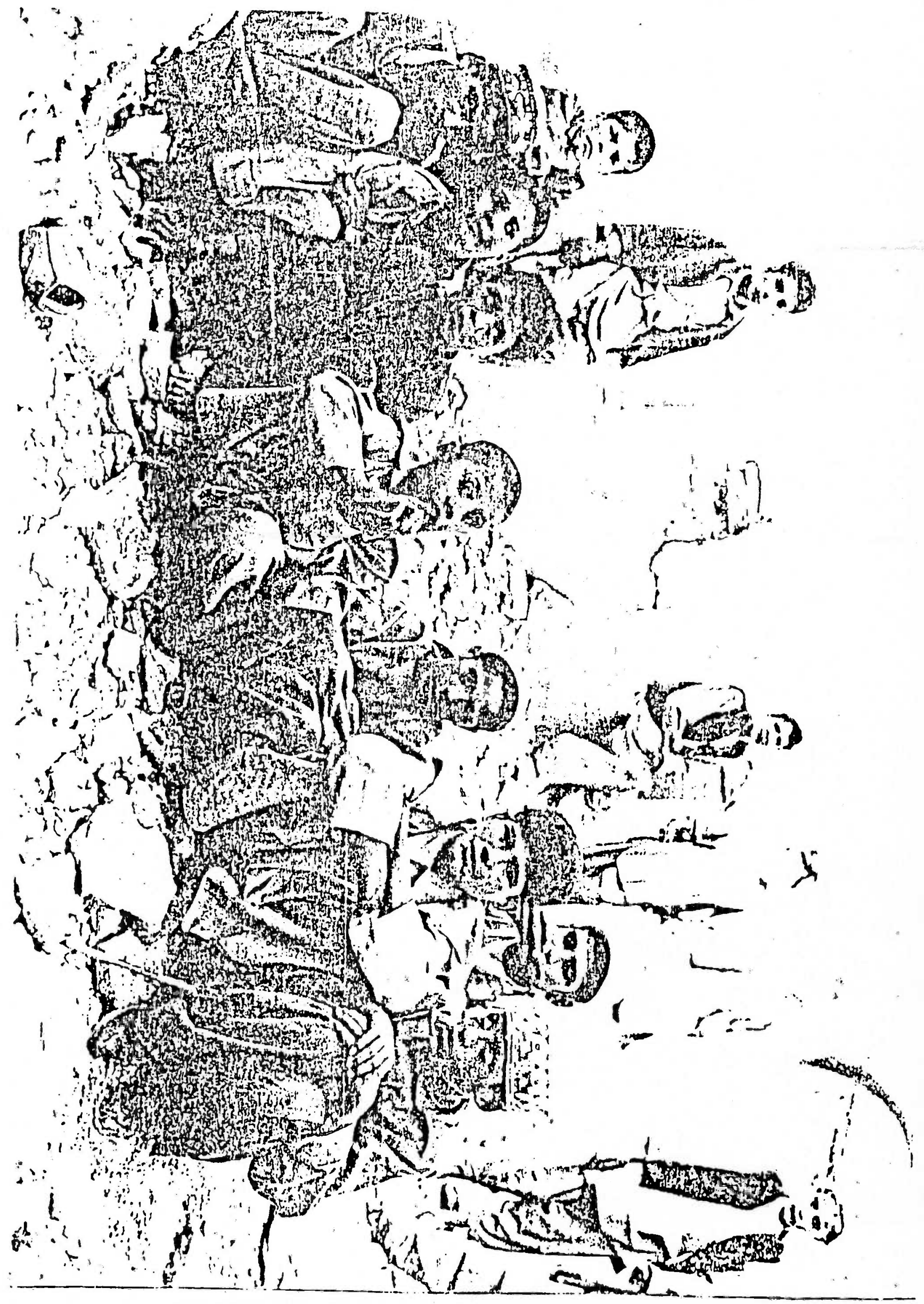




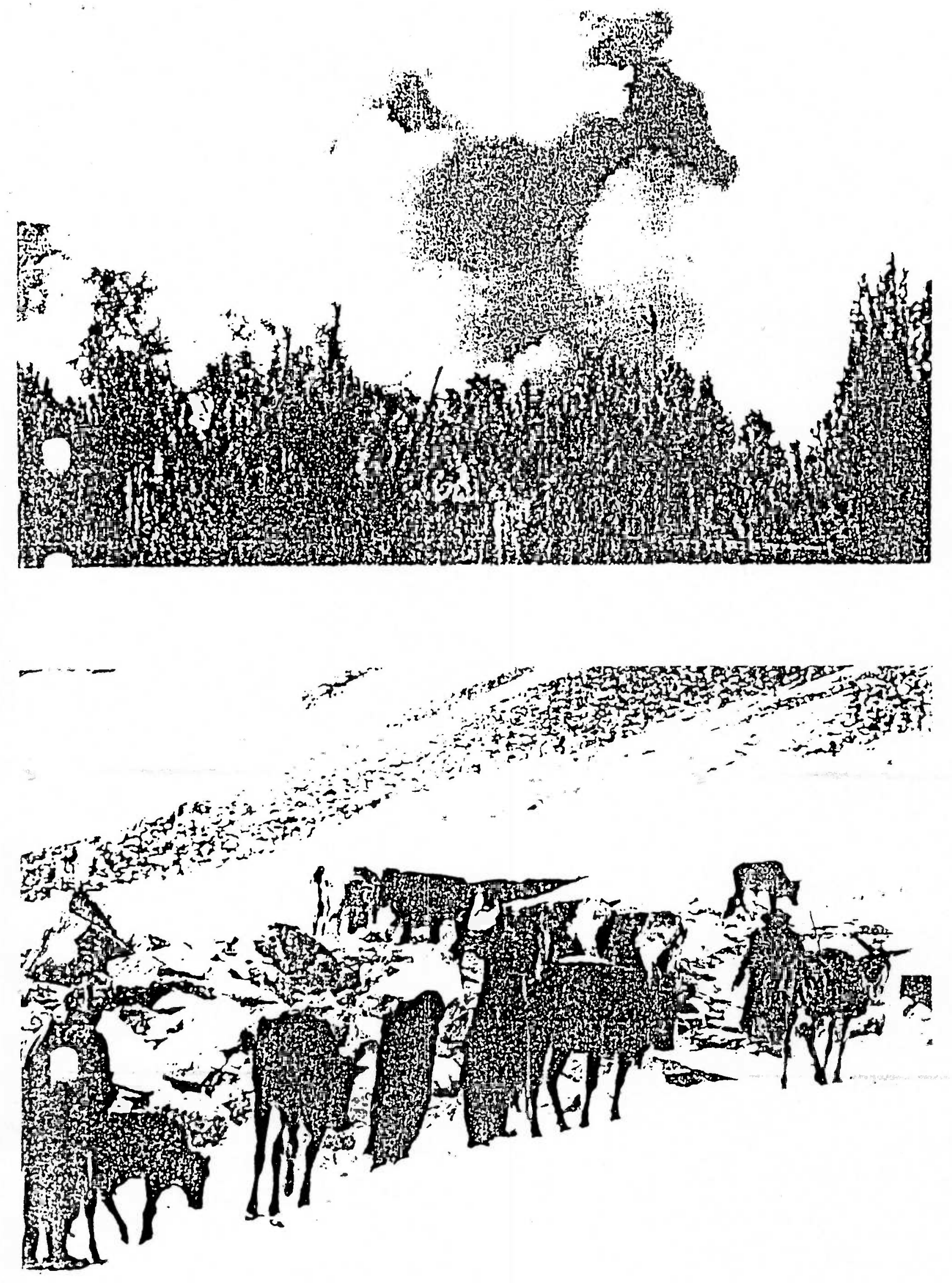




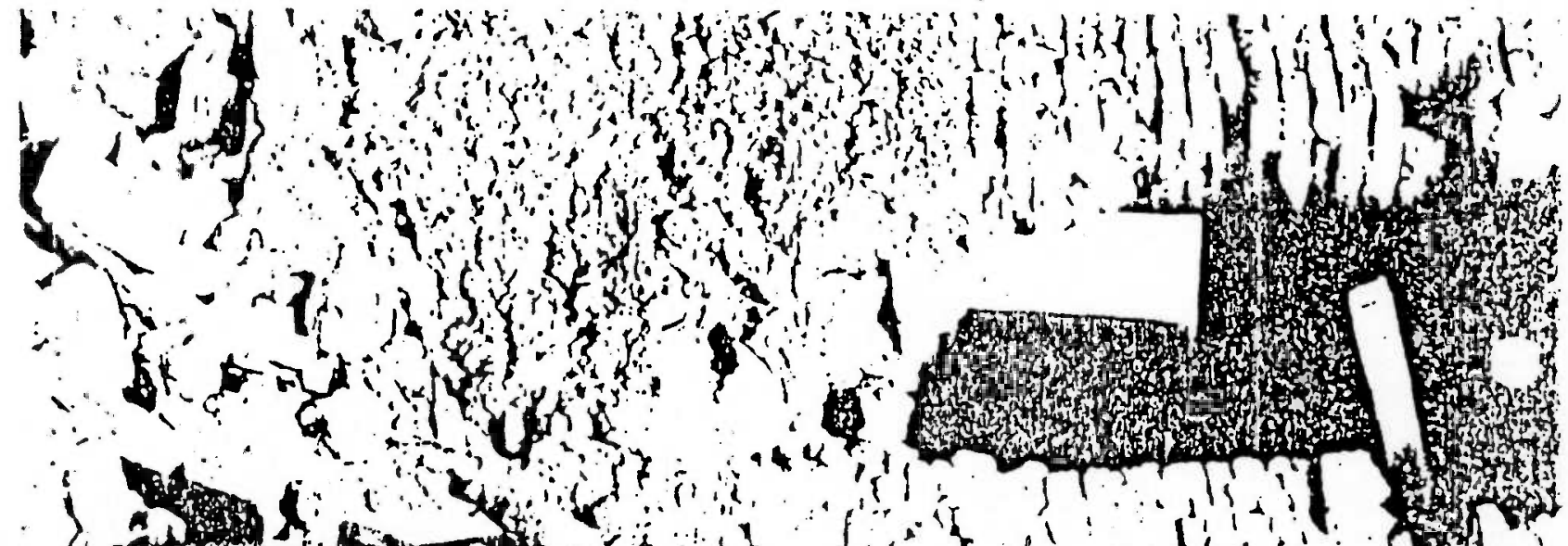

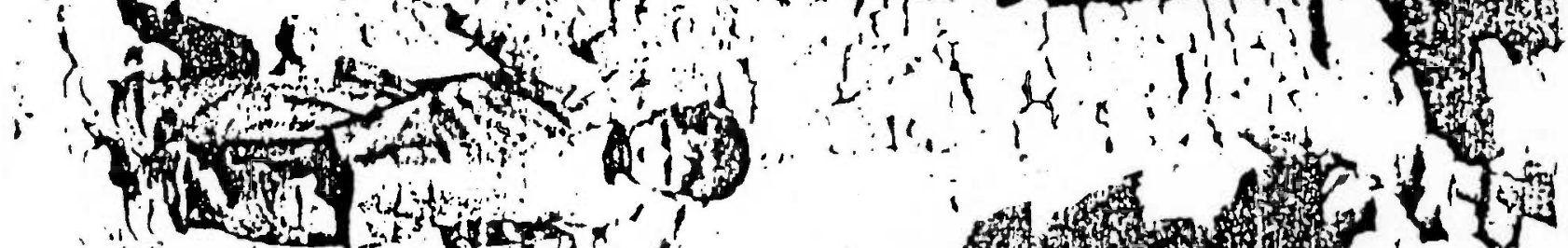

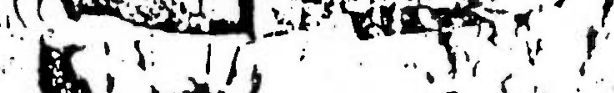

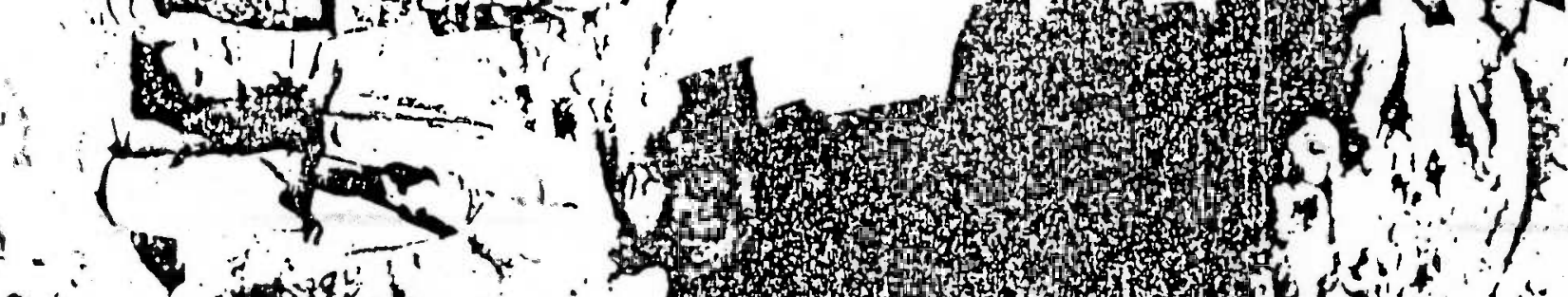

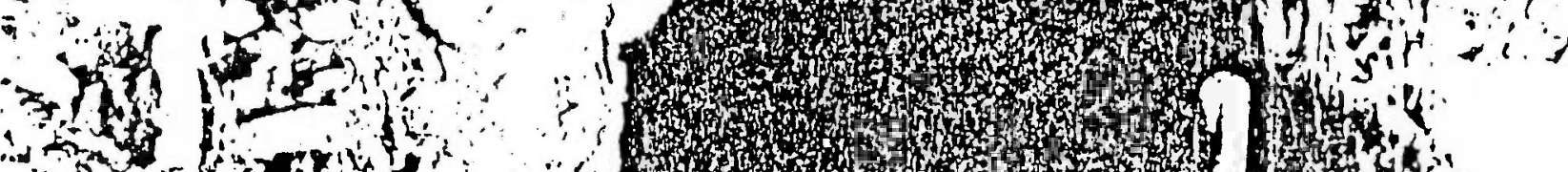

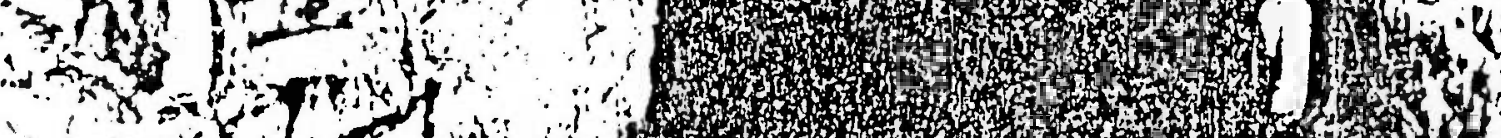

a :

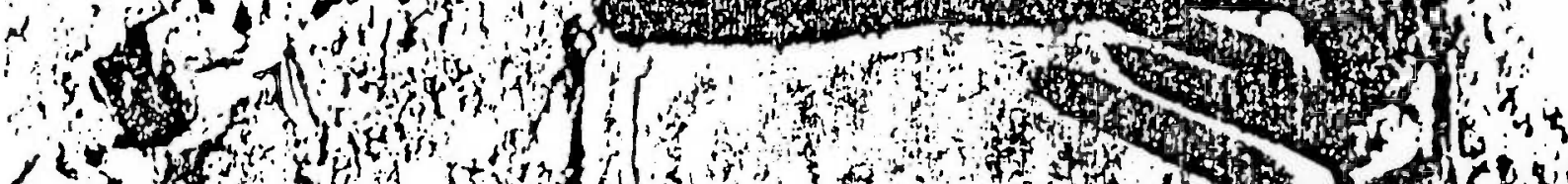

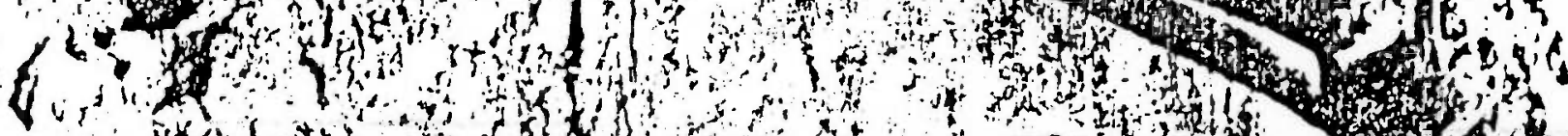

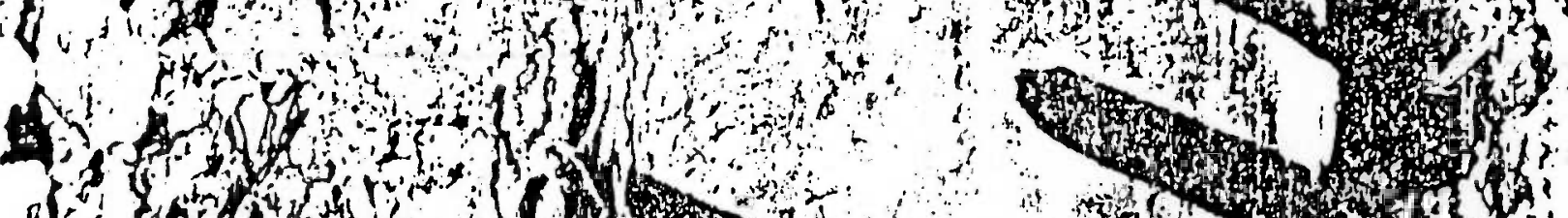

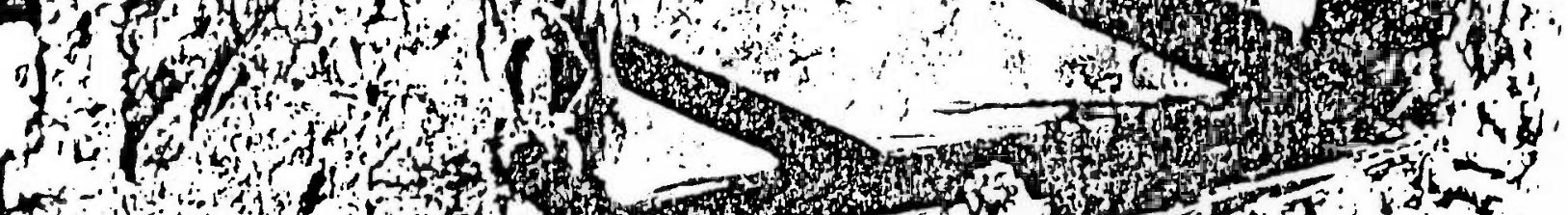
150 of कृ an,

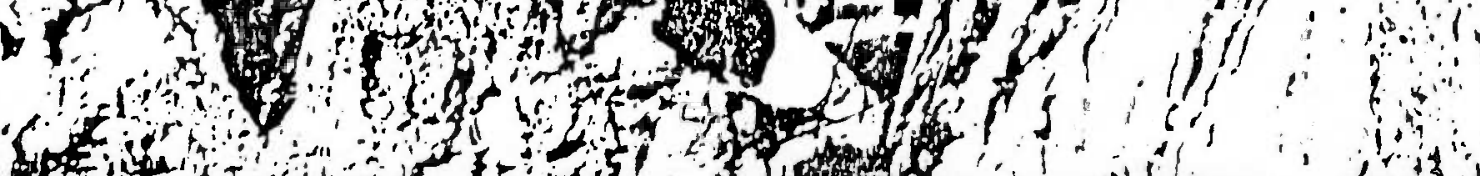
How 


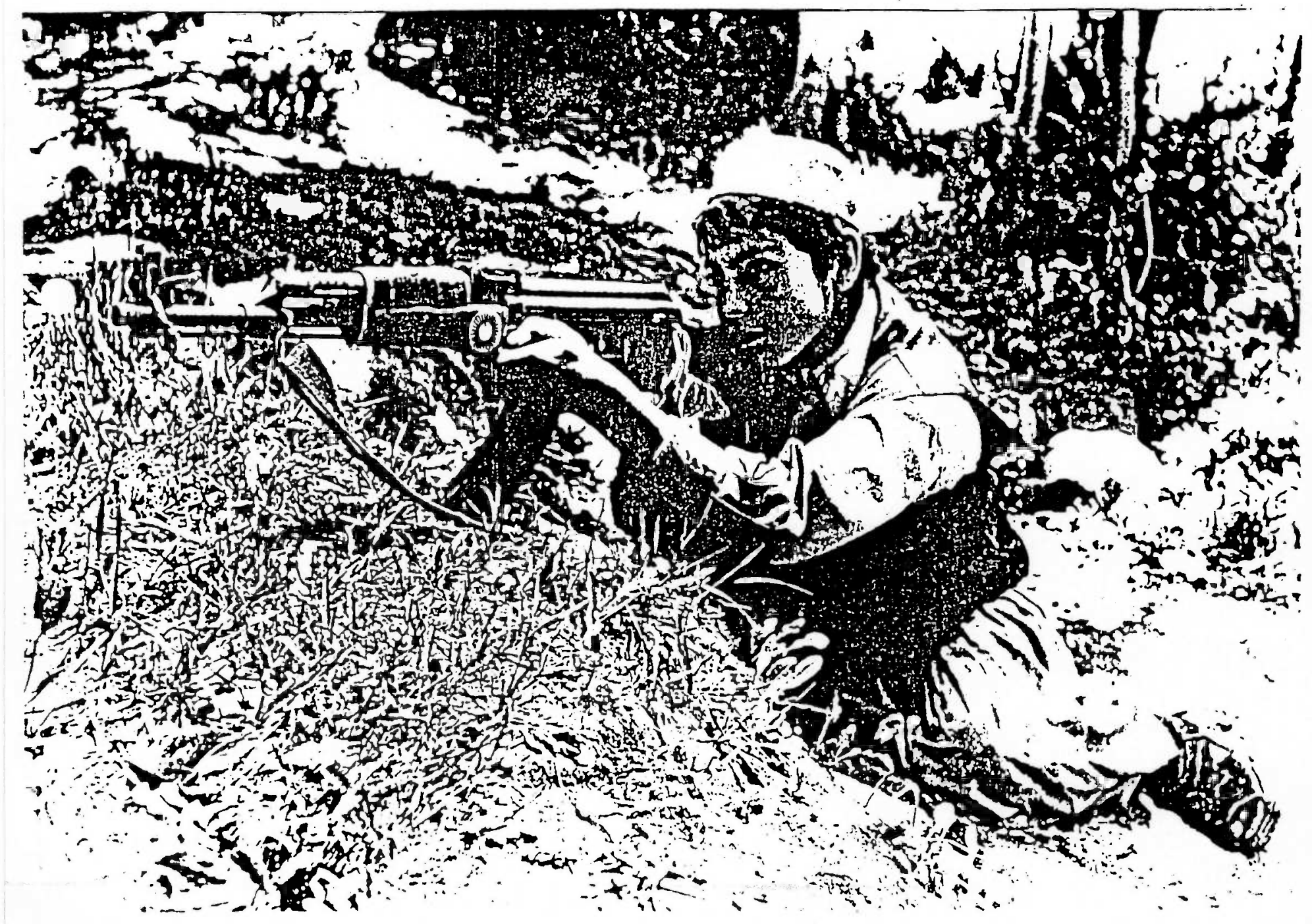




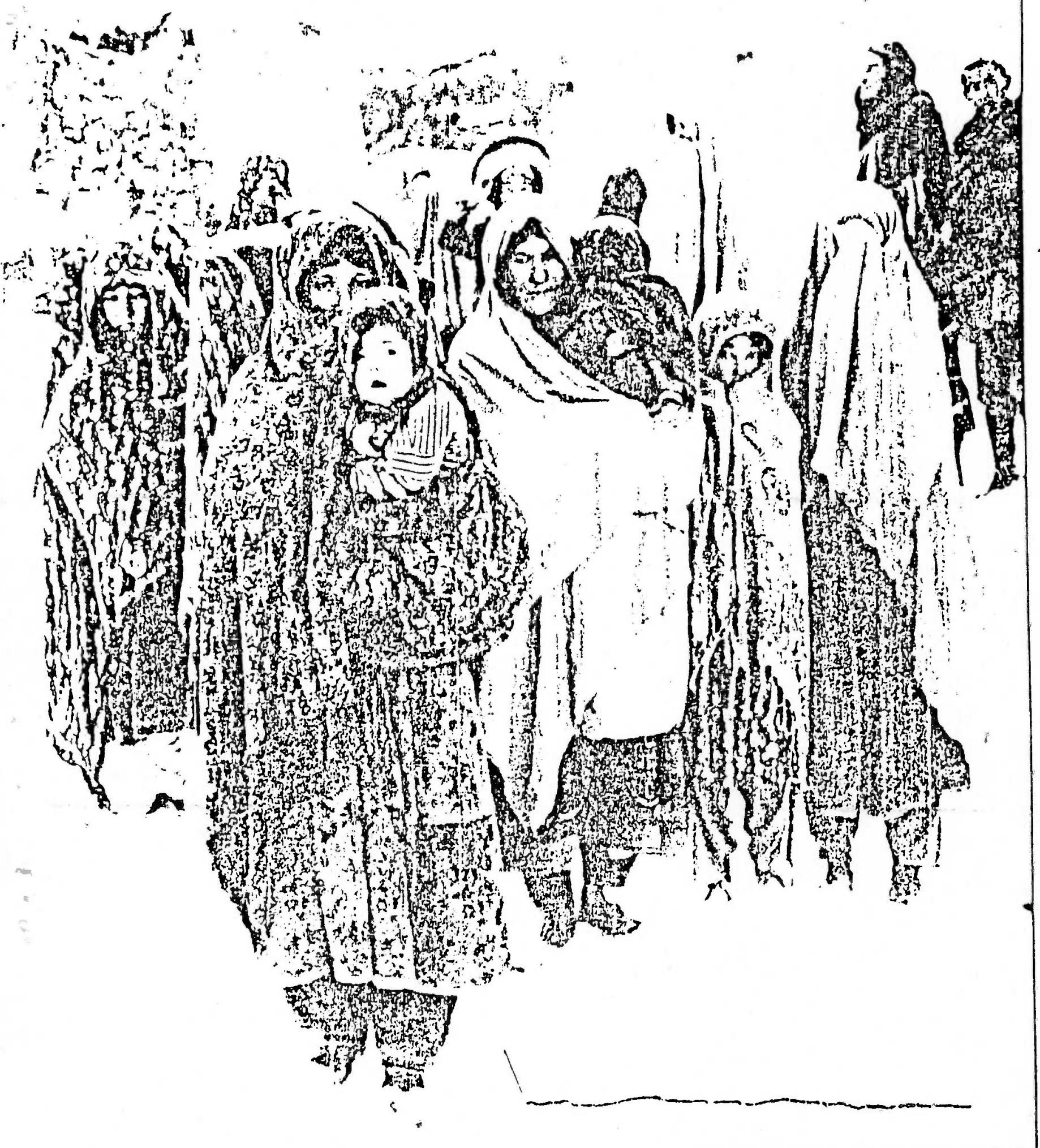




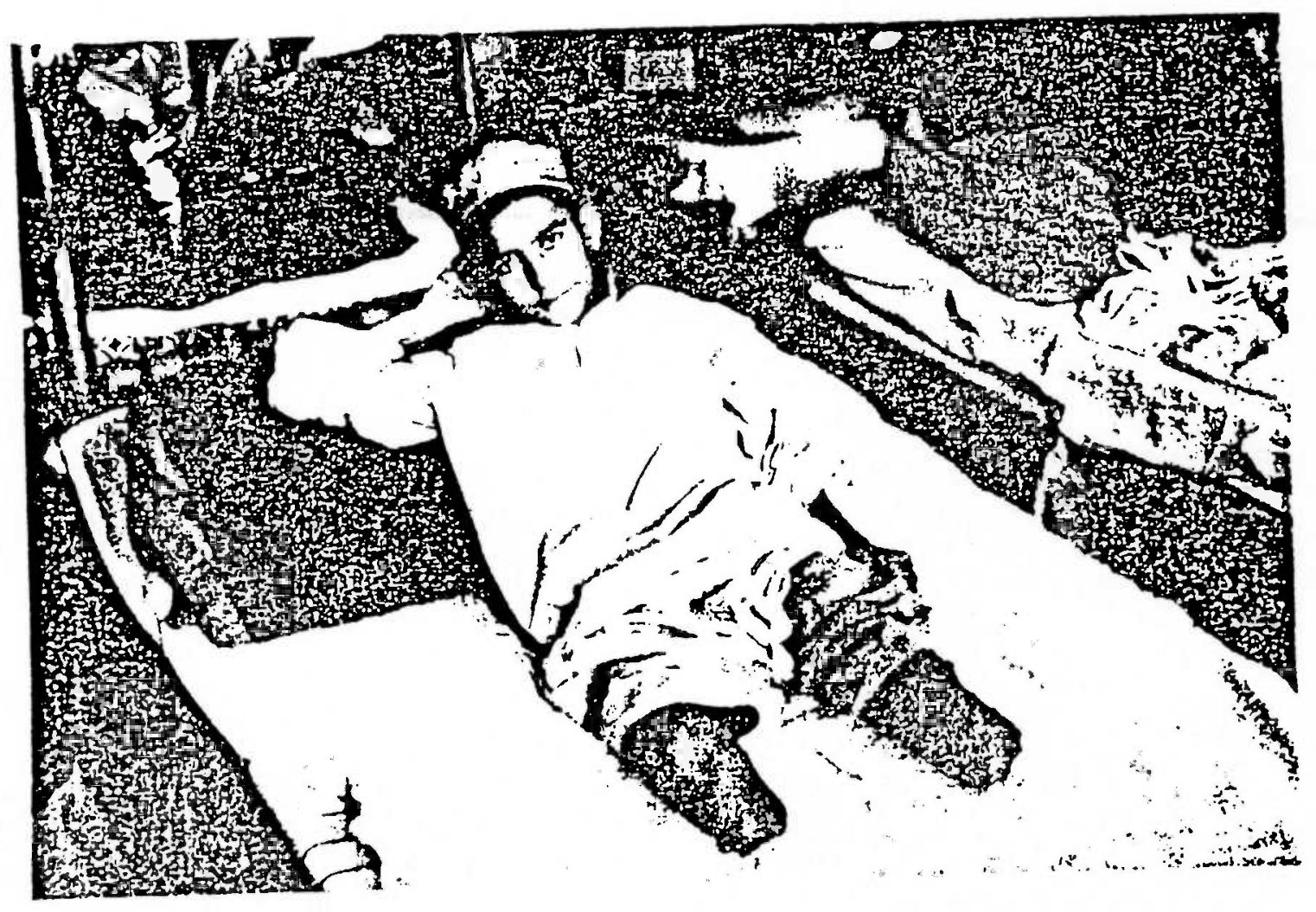


